E-Journal of Tourism Vol.8. No.2. (2021): 215-228

\title{
A Proposed Partnership Scheme of Bangkok Mass Transit System (BTS) and MICE Corporations: Passenger Satisfaction and Tourism Transport Policy Approach
}

\author{
Pem Dechen, Sittichai Sanyost, Ahmad Mujafar Syah* \\ Naresuan University International College, Thailand \\ *Corresponding Author: ahmadmu@nu.ac.th \\ DOI: https://doi.org/10.24922/eot.v8i2.74318
}

\section{Article Info \\ Submitted: June $17^{\text {th }} 2021$. Accepted: September $19^{\text {th }} 2021$. Published: September $30^{\text {th }} 2021$}

\begin{abstract}
This research examined and proposed a partnership scheme between Bangkok Mass Transit System (BTS) and MICE corporations (MICE: meetings, incentives, conventions \& exhibitions) where one representative from BTS and six respondents from six different MICE corporations volunteered in the study. The research was conducted by two different sequences and undertaken by a mixed methodology. Out of 400 ridership satisfaction questionnaires, 300 were validated to have ridership experiences to MICE venues with BTS. Post-passenger satisfaction study, the results were used to inform BTS and MICE corporations to navigate in-depth interviews. SPSS runs to quantify travel frequencies, demographic profiles, and passenger satisfaction while thematic analysis framed the interview results. The finding underscored the two major significances as they correspond to the objective of the study: (1) The overarching governance proposal of BTS's short-term partnership scenario with MICE corporations - where an informed policy benchmark from "England Strategic Action Plan for Tourism 2010-2020" robustly examined; (2) the novelty over the deficient study of integrated transport-MICE strategic planning within the Southeast Asian region.
\end{abstract}

Keywords: Partnership scheme, Passenger satisfaction, Bangkok Mass Transit System (BTS), MICE corporations

\section{INTRODUCTION}

Revisiting the growth of the travel and tourism economy in Thailand, prior to the pandemic, the Kingdom's tourism has been progressing from 8 million visitors to 39.92 million by the end of 2019 - the great and remarkable improvement over the past 2 decades (Ministry of Tourism and Sport, 2021). The tourism revenue generated as of 2019 was recorded at 2 trillion Baht with industry job absorbance at 7 million workforce or up to $20 \%$ of the total employment (Bank of Thailand, 2021). These tourism receipts have contributed a solid industry growth at $11 \%$ of the total country's GDP (Bank of Thailand, 2021). Additionally, with regard to TCEB (2019) and Meet in Thailand (2020), the growth of the MICE (Meetings, Incentives, Conventions \& Exhibitions) industry has been contributing an impressive international exchange reve- 
nue since 2010, marked by the numbers of MICE travelers were constantly skyrocketing from 679,585 to $1,280,000$ per 2017. As reported in the tourism \& travel competitiveness index 2017, distributed by the World Economic Forum, among the 136 countries worldwide, Thailand has been ranked $34^{\text {th }}$ and is ranked $3^{\text {rd }}$ among southeast Asian members and standing below Singapore and Malaysia (Meet in Thailand, 2020). In 2018, Thailand Convention and Exhibition Bureau (TCEB) has planned the actual number of 1,340,231 international MICE individuals to Thailand, generating revenue of 3.4 billion US dollars alone equal to 109 billion baht. Thailand's MICE industry is indeed progressing its operational service capabilities. With a clear mission of Bangkok Metropolitan Region (BMR), and TCEB as a public body for MICE business administrators in Thailand, their core mission is to create and improve the competitive MICE industry environment. As TCEB (2019) mentioned, the 4 key objectives of MICE capability are concisely communicated as extending the knowledge to new generations of future leaders; elevating capabilities through knowledge, content sharing, networking, promotion, and marketing activities; expanding support for domestic and international trade alliances; as well as enhancing service and operational quality to international standards.

With the same critical degree, over the surge of domestic and international visitation for Thailand's MICE, the transport system has been serving fundamental logistics and its integrations cannot be left trivial. According to Celiński and Sierpiński (2014), the transport system strongly influences other businesses, especially those around the areas nearby. When it is managed in a manner that all transport infrastructures, residents, and visitors are well integrated upon, the positive externalities of this travel economy system could pay out the overall establishment and re- gulatory expenditures (Albalate \& Bel, 2009). It drives positive externalities where inevitably, urban people depend heavily on their socioeconomic benefits (Celiński \& Sierpiński, 2014). Through that holistic socioeconomic expectation, Bangkok, as the capital city, has to be very sensitive in adapting to the needs of urban mobility including its major source of economy, the tourists. With so many existing benchmark studies on logistics in response to tourism growth, Bangkok needs to enable a keen outlook on the mutual linkages between business sectors, which in this case, includes a partnership of BTS with MICE venues.

The Bangkok Skytrain or best known as the Bangkok Mass Transit System (BTS) has been operating since 1999. It is the first electric mass transit railway system to begin operations in Thailand and endeavors to increase the paths in the suburbs of Bangkok so that it can transport more residents and tourists to a wider area of Bangkok (BTS, 2019). The BTS trains have offered the right direction in solving the public transport issue within a packed metropolitan area. The sky train consists of a 36.92 kilometers elevated railway system that operates above the street system in Bangkok. BTS has two lines that it operates, the Sukhumvit Line and the Silom line. There are today 35 stations along two routes (BTS, 2019).

With the fact that BTS has rapidly served the ridership; through the support of transit facilities such as safe and convenient pedestrians, well-joined road links around the transit terminals, rooms for disabling access both in and out of the BTS transit terminals, clear and safe circulation lines of passengers within the terminal, and good rush hour management (Noichan \& Dewancker, 2018), BTS still has many problems posed by inconvenient transit trips from several transfers such as packed connection areas, frequency and punctuality issues, and difficult access for disabled riders 
(Noichan \& Dewancker, 2018). In addition, BTS has not yet achieved the main goals to reduce the number of private vehicles and attract more ridership (Noichan \& Dewancker, 2018).

Despite the critiques, BTS has proven to be one of the fast-growing logistics infrastructures and the largest leading service industries in Thailand. It satisfied many passengers' means of transportation, and its rapid economic growth has been constantly progressing. Passengers from so many different backgrounds, including MICE travelers, rely on this mode of transportation. Nevertheless, the satisfaction study from BTS' passengers' point of view has not yet been explored. Likewise, resonating to previous research in mass transportation for a city and its support toward the development of MICE industries, especially within the context of Thailand, the researchers found that in addition to infrastructure, service, congestion, and transit issues in BTS, there are insufficient studies recommending the contemporary of partnership strategy on how mass transportation within a city like Bangkok being governed benefiting all the stakeholders including the passengers, MICE corporations, and tourism businesses as a whole. Thus, the research on how the governance within the Bangkok Mass Transit System (BTS) being adapted to reach out to the MICE tourists commuting with BTS and how the integrated collaboration between BTS and MICE venues being strategically proposed and implemented is becoming an important study to explore.

\section{LITERATURE REVIEW}

\section{Passenger Satisfaction on Integrated System of Public Transport}

On the basis of a customer satisfaction study, Shiau and Luo, 2012 argued that meeting customer satisfaction is pivotal for a corporation's long-term credibility. This also would stimulate a continuous mutual http://ojs.unud.ac.id/index.php/eot relationship between the market and the brand (Shiau \& Luo, 2012). From customers' demand perspectives, sustainable and integrated modes of transport will soon transform the travel demand's behaviors. Customers would tend to progress to a more efficient pick up on modes of public transportations that are not only committed to green technology but also more integrated and safer, punctual, and reliable (Replogle \& Fultorn, 2014). Afrer all, as Replogle and Fultorn (2014) extended, the passenger satisfaction understanding among the public transport id framed as where the passenger has a default service delivery expectation, the concept of actual ridership experience, as well as perceived specific satisfaction indicators of a certain public transport for a certain group of individuals. Depending on what public service's indicators a researcher would exercise for the purpose of his/ her satisfaction study, most commonly, the study would lead to the literature review of service quality in transit systems from which diversified factors of passenger's satisfaction are based (de Ona, et al., 2012).

The nature of the mass transportation system in the city that is owned by the public enterprise and/or semi-private ownership is generally monopolistic where the competitions are extremely rare (Pavlina, 2015). Extending to the mentioned fact, while the other private companies are grasping the principles of a solid company culture towards customer priority, the public enterprises are hypothetically seen with less focus of customers' satisfactions, and hence, putting aside a customer's input is not unusual (Pavlina, 2015). "Therefore, in public and/or semi-private firms, the view of the customer is often omitted whereas in economics and marketing, this kind of view is widely studied (Mouwen, 2015). Having said that, in order to receive the overall rating of service quality within the mass public transport system in the city, regardless of the measurement of which service being 
tested, the passenger satisfaction is vital (Pavlina, 2015). As much as we understand that either private companies, or public enterprises, or the combination of both are praising the service excellent principles to maintain their values and overall portfolios. And without undermining the respective nature of the company's capitals, the voices from the customers should never have been left trivial. Especially, when we want to rebuild or seek another strategy on customer engagement and service quality excellence through mutual business partnerships (Pavlina, 2015).

According to Antonucci, et.al. (2014), the factors to studying customer satisfaction toward public transport are divided into two categories, from each of the subcategories entitled with significant details. There are: Observed variables that include service organization, safety, reliability, human resources, comfort, and cleanliness. De Ona, et al., (2013) resonated the indicators of observed variables that lie within a service indicator ranging from speed, frequency, and punctuality of transport, and information whereby these indicators may navigate the level of passenger satisfaction at its highest rate. Meanwhile, the second category is latent variable. This variable included the perceived service quality and delivery, and logistics parameters (Antonucci, et.al., 2014 \& Pavlina, 2015).

To support aforementioned passenger attributes for a benchmark's research framework purpose, research by Mouwen (2015) further explained that based on the case study in the Netherlands, the customer opinion on public transport may range from service attributes on-time performances, travel speed, service frequency, driver behavior, and the cleanliness of the vehicles. However, to compare it fairly, the passenger satisfaction study in the Netherlands may differ from any other countries due to its exceptional logistics systems on bicycles and high fare of public transports are inevitably affecting special satisfaction attributes (Pavlina, 2015).

As this study extends the study from Pavlina (2015) albeit with more emphasis on observed variables, the association between BTS's current operations and Pavlina (2015) is considered more cohesive as the satisfaction indicators presented adhere to what BTS is currently lacking in customercentered study. Pavlina (2015) has done the study within the Czech Republic's city transport condition. Pavlina (2015) furthered the indicators of passenger satisfaction on public transport, based on different buying behavior, travel motive, the demographic structure of passenger, the statistics of tourist in the targeted research city, through the satisfaction framework of "optimal model" as shown in table 1.

\section{A Proposed Strategic Partnership Scheme from England's Strategic Ac- tion Plan for Tourism 2010-2020}

"Transport is acknowledged as one of the most significant factors to have contributed to the international development of tourism" (Page, 2005, p. 3). The tourism economics may rely heavily on integrated transport systems as people are moving within a destination by predominant full factors of urban centers attractiveness and in integrated public transports (Page, 2005). This is, therefore, as Page (2005) added, prioritizing a system approach of traveling through advanced connections of the public transport systems is an integral part to supporting travelers' decision-making processes prior to their visit to the destination. "These elements are linked, in the first instance, by the flow of information followed by visitors traveling between originating and receiving destinations" (Page, 2005 p. 14). In order for all these processes to happen, the integral intermediaries are public transport systems (Page, 2005; Lumsdon, 2004; Mill \& Morrison, 1992).

Lumsdon and Page (2004b, p. 1) e-ISSN 2407-392X. p-ISSN 2541-0857 
Table 1. Satisfaction with Public City Transport - The Optimal Model

\begin{tabular}{ll}
\hline Latent variable & \multicolumn{1}{c}{ Observed variable } \\
\hline & Timetable clarity (timetables on the public transport stations are clear) \\
& problem) \\
& Vehicles cleanliness (insides of vehicles are clean and maintained) \\
& Information (information in the public transport vehicles such as maps, sta- \\
& tion signal, is sufficient \\
Service & Transport comfort (traveling in the public transport is comfortable regardless \\
& of season; summer or winter) \\
& Safety (travelling in the public transport is safety) \\
& Transport speed (transport speed is satisfactory with regard to the traffic situ- \\
& ation) \\
& Punctuality (punctuality of public transport is precise and unfailing) \\
\hline & Transport comfort (traveling in the public transport is comfortable regardless \\
& of season; summer or winter) \\
& Punctuality (punctuality of public transport is precise and unfailing) \\
& Service continuity (service continuity is time and space manageable; it means \\
Logistic param- & that transport changes are not complicated) \\
eter & Frequency (frequency of public transport is sufficient with regard to the num- \\
& ber of passenger) \\
Transport speed (transport speed is satisfactory with regard to the traffic situ- & ation) \\
Fare (fare including price and validity is affordable)
\end{tabular}

Source: Pavlina (2015)

deepened the theoretical understanding of integrated public transportation systems through the perspectives of tourists as the end users: "the development of a theoretical framework of analysis has focused on a systems approach. The tourist system is defined by McIntosh, et al. (1995, P. 21) as a "set of interrelated groups coordinated to form a unified whole and organized to accomplish a set of goals". Likewise, according to Mill and Morrison (1992), the tourism system is a cycle of exchange processes where the market, the travel supports (e.g. transport, hotel), the destination, and marketing schemes are integrated in a mutual manner.

From the economics perspective, the endeavors of a state toward the traveler using public transport must be unyieldingly

http://ojs.unud.ac.id/index.php/eot

supported by the cooperation of public and shareholders due to the nature of transport economist of transport in leading and examining the different types of transport modes and their competitiveness such as the relation to price, speed, convenience, and reliability (Page, 2005). Page (2005 p. 37) "economists attempt to understand what affects people's travel behaviors and the choices they make in relation to transport (i.e. travel choice modeling) is something that is rarely consumed for its own sake". It generally means, as Page (2005) added, the consumption of services as a whole package (i.e. traveling to work and leisure by public transport). According to Mill (1992 p. 83) "the demand for transport in alignment to tourism is also characterized by (1) instantaneous and unpredictable na- 
ture of demand where the operators are imposed to manage the overcrowded supplies mechanism to avoid travelers' dissatisfaction; (2) derived demand where a traveler is using public transport for business purposes - and primary demand where the travelers fulfill the pursuit of their vacation purposes; (3) lastly, non-prices items (e.g. service quality, reliability, and punctuality).

At this point, even though this economic theory was not exclusively written for the purpose of passenger satisfaction, Ortujzar, and Willumsen (1991) argued that economic factors influencing the demands of travelers to decide which destination is appropriate. Thus, the economic fulfillment and/or value of money can be assessed by looking at socioeconomic factors (e.g. age, income, profession, and family status). And thus, this research elaborates the combination of those factors from Pavlina (2005) and Ortujzar and Willumsen (1991) in the demographic variables.

As a descriptive analysis, rather than adopting the transportation-tourism theory, this research would enable the informed policy on public transport in the UK and whenever applicable, would emphasize the existing policy with BTS's strategy on partnering with MICE corporations in Bangkok. In this case of England, the tourism sector has been the major contributor where public transport adaptability toward inclusive service delivery is imperative. Moreover, policy study on transport and tourism provides a vast array of examinations on indicators by which a certain developing state may be able to utilize (Page, 2005). With a thriving service industry in the UK of $79.2 \%$ based on the Central Intelligence Agency report in 2017 and its commitment toward the environment and pollution control, policy interventions as well as global co-operation (OECD Report, 2017), the UK has been a global lab for sustainable public transport, environmental commitment research and tourism econo- mics studies. In a sequence manner, benchmarking a policy tool from England's Strategic Action Plan for Tourism 2010-2020 (Short-Term Action) is the right decision. It is able to navigate the action-plan mapping between the public transport management in the city, region, or a country and related supporting industry within the policy action of three years (short term) shown in table 2. The decision to exercise the "short-Term Action" solely because of the partnership scheme study between BTS and MICE corporations is found to be new for Thailand context, the policies of England's Strategic Action Plan for Tourism 2010-2020 on three to five years (medium-term), and ten years (long term) are not examined.

After all, this research has been merely employing the passenger satisfaction' theory from Pavlina (2015) and a policy tool from England's Strategic Action Plan for Tourism 2010-2020. The study was not constructed by any theoretical framework for a specific research area of Bangkok. Thus, both satisfaction and partnership proposals in the result section are purely a product of benchmarking contests.

\section{METHODS}

This research implemented mixed methodology. A quantitative method was conducted for the first phase of this research by enabling the data collection whereby 400 samplings on travel frequency of BTS's ridership to MICE venues was distributed. 300 validated samplings with prior travel experiences with BTS to MICE venues were proceeded, as to find ridership satisfaction rates in that matter. While the preliminary survey on travel frequency to MICE venue with BTS was modified by the authors, the demographic data (gender, age group, education \& nationality) was gained from a previous study by Pavlina (2015) and Ortujzar and Willumsen (1991) and the satisfaction questionnaires for 
Table 2. Short-Term Action (3 years)

\begin{tabular}{l} 
ACTION \\
\hline i. Identify ways to minimize \\
weekend and Bank Holiday rail \\
closures and other such events \\
through investigating alternative \\
maintenance solutions and/or \\
scheduling
\end{tabular}

ii. Identify examples of best practice in the coordination of public transport services between transport modes and destinations.

iii. Work with operators to achieve greater coordination in terms of information provision, communication and timetabling.
LEAD PARTNERS

(where appropri-

ate)

$\begin{array}{ll}\text { Association of } & \text { Department for Transport (DfT); } \\ \text { Train Operat- } & \text { Local Authorities; Greater Lon- } \\ \text { ing Companies } & \text { don Authority (GLA); Transport } \\ \text { (ATOC) } & \text { for London (TfL); Network } \\ & \text { Rail; Campaign for Better } \\ & \text { Transport; academic partners; } \\ & \text { Destination Organizations }\end{array}$

Academic partners; Destination Organizations; VisitEngland transport operators

\section{ATOC}

DfT; Network Rail; Local Authorities; transport operators; Campaign for Better Transport; Destination Organizations; VisitEngland; academic partners; VisitEngland

iv. Promote use of travel plans for tourism businesses, destination organizations and local authorities delivering tourism services.

v. Simplify and improve rail pricing, ticketing restrictions and packages for leisure users e.g. development of smart cards for leisure users.

vi. Work with the DfT to influence leisure journey times and minimize peak period holiday disruption.

Encourage coordination between the transport sector and major events through identifying and sharing case studies on the benefits of working together.

Demonstrate that transport, tourism and wise growth can work together and offer solutions to transport problems for visitors, employees and residents alike.
Sustainable

Transport - British

Cycling Organiza-

tion (SUSTRANS);

Good Journey

ATOC

DfT

Destination Management Offices
Local Government Association (LGA); Local Authorities; motoring organizations

Destination Organizations; tourism businesses; Visitor Attractions Group

Network Rail; transport operators; Highways Agency

ATOC; motorists organizations; academic partners

National Park Authorities; SUSTRANS; academic partners; Visit England
OUTCOME OR SUCCESS MEASURE

Number of complete line

closures over weekends reduced

through local agreements; evidence of partnership working between DMOs and Train Operating Companies to reduce visitor disruption; evidence from destination organizations to demonstrate improvements.

Case studies to be published (including updates on work in progress); promote best practice examples e.g. development of public transport leisure services (leisure routes); leisure traffic management; integrated transport schemes (e.g. York).

Campaign for better transport information for tourists; simplified ticketing and access to market; seek sustainable transport solutions including use of local public transport by visitors and alternatives to use of the car at destinations; recognized improvement in information provision with cited examples; better web-based integrated travel information and access to apps; case studies to be published.

Publish examples of tourism businesses promoting best practice and features through VE corporate resources.

Examples of improved provision for leisure travellers; integrated 'tourist' ticket offers

Set up Intergovernmental Working Group/Task Force to oversee improvements to service.

Case studies to be published and disseminated; better use of transport sector collateral (opportunities to advertise or to promote) and to inspire travel by public transport using mixed media.

Dissemination of best practice that can be adopted throughout destinations, especially in more remote or rural areas or parts of England poorly served by public transport.

Source: Adapted from England - A Strategic Action Plan for Tourism 2010-2020 
MICE travel purposes were modified from Pavlina (2015). Then, purposive sampling was chosen, due to the classification of travel intention that was targeted merely to the passenger with Bangkok's MICE travel experience with BTS. 300 purposive samplings were considered representative as it represents the total of BTS's population from the actual average ridership report in 2018 from Krungsri (2019) at 723,851.

For the qualitative method, 1 public relation \& marketing manager from BTS, and 6 different senior managers of MICE corporations, with extensive MICE event leads within the greater Bangkok metropolitan areas, volunteered for in-depth interviews. The selected respondents justified the sample size towards data "saturation point", which when sufficient, generates no newer content (Goulding, 2017; Shaw, 1999).

While the respondent data managerial position for BTS is not classified as per prior respondent's consent, personal profile of passengers, BTS, and MICE corporations' personal profiles, as well as MICE corporation portfolios, were not at all disclosed. A pilot study of 30 pre-questionnaires and 1 pilot interview was conducted prior to the actual data collection. All pilot, actual surveys distributions, and interviews were collected from September 2019 to March 2020.

As this research is intended to provide an extensive descriptive analysis from the data of passenger satisfaction on BTS accessing to MICE venues, and led to the result of in-depth interviews from BTS managers and MICE corporations on the strategic partnership scheme that benefit both passengers and participating organizations, the hypothesis is not run. Nevertheless, the passenger satisfaction survey results were used to supplement the information sharing to both BTS and MICE corporations on the current passengers' issues. The satisfaction result would also build constructive study recommendations on what effects do the highest, moderate, and lowest responses on passenger satisfaction influence the strategic actions of a better partnership between BTS and MICE corporations and within Thailand context. In addition, for in-depth interview purposes, a policy benchmark on tourism and transport schemes from a report of England's Strategic Action Plan for Tourism 2010-2020 was benchmarked to navigate the framework on the partnership schemes between BTS and MICE corporations.

The quantitative data were analyzed by SPSS software in order to gain the frequency of demographic data, and the percentage of satisfaction responses. Both travel frequencies and satisfaction rates were measured by employing five-point Likert scales. The Likert scales ranging from 5 (Always) to 1 (Never), and 5 (Strongly Satisfied) to 1 (Strongly Dissatisfied) respectively. The interview transcripts were coded using the thematic analysis where the responses from BTS and MICE corporations were coded and then framed respectively reflecting the policy tool of England's Strategic Action Plan for Tourism 2010-2020 (Short-Term Actions). The policy benchmark utilized for navigating the partnership proposal map of BTS and MICE corporations.

\section{RESULTS AND DISCUSSION}

\section{Passenger Satisfaction in Accessing MICE Venues with Bangkok Mass Transit Systems}

The collected data was analyzed and presented as follows: The respondents, passengers using the BTS, $(\mathrm{N}=400)$, were asked to answer a pre-constructed statement based on their experiences to access the MICE venues in greater Bangkok metropolitan areas by BTS.

With 300 surveys validated for having experiences traveling to MICE venues 
with BTS, the surveys progressed by collecting 10 factors of passenger satisfaction in accessing MICE venues with BTS. Prior to that, the demographic data based on Pavlina (2015) and Ortujzar and Willumsen (1991) explored gender, age group, education, and nationality of the respondents were also sought out.

Table 3. Preliminary Survey on Travel Frequency to MICE Venues with BTS

\begin{tabular}{ccc}
\hline $\begin{array}{c}\text { Preliminary } \\
\text { Survey }\end{array}$ & Likert Scale & $\%$ \\
\hline & Always & $16 \%$ \\
Travel Frequency & Most of the time & $34 \%$ \\
to MICE with & About half the time & $19 \%$ \\
BTS (N=400) & Once in a while & $6 \%$ \\
& Never & $25 \%$ \\
& & $100 \%$ \\
\hline
\end{tabular}

\section{Simulation of England's Strategic Ac- tion Plan for Tourism 2010-2020 on Bangkok Mass Transit System (BTS) and MICE Corporations}

Post-passenger satisfaction results on the BTS adaptability to support trips to MICE venues, in-depth interviews proceeded to targeted respondents of BTS and MICE corporations. Due to time constraints in this research, and the fact that both BTS and MICE corporations are new to this proposed partnership idea, the examination of the approach on a policy tool of England's Strategic Action Plan for Tourism 20102020 would only be focused on Short-Term Action (3 years) as the guiding term actions according to the short-term policy emphasized. The short-term England's Strategic Action Plan for Tourism 2010-2020 would mean the assessment of maximum achievement of the partnership can be utilized by solely implementing the least amount of project and/or partnering costs, "especially where different sectors/sub-sectors fail to work together or fail to engage with destination managers, event organizers, DMOs and local authorities" (England's Strategic Action Plan for Tourism 2010-2020, p.8). It sets the pilot partnership guidelines with a collaborative outcome projection of three years. In other words, the approach of this "Short-Term Actions (3 years)" would fit the most when only two parties (BTS \& MICE corporations) first attempt to manage the partnership scheme despite the variety of delivery partners as highlighted in this policy.

Table 4. Demographic Profile of Respondent (Validated N=300)

\begin{tabular}{|c|c|c|c|c|c|}
\hline Item & $\mathrm{N}$ & $\%$ & Nationalities & $\mathrm{N}$ & $\%$ \\
\hline \multirow{4}{*}{$\begin{array}{l}\text { Gender } \\
\text { Male } \\
\text { Female }\end{array}$} & \multirow{4}{*}{$\begin{array}{l}129 \\
171\end{array}$} & \multirow{4}{*}{$\begin{array}{l}43 \% \\
57 \%\end{array}$} & Thai & 139 & $46 \%$ \\
\hline & & & Chinese & 48 & $16 \%$ \\
\hline & & & Singaporean & 6 & $2 \%$ \\
\hline & & & American & 16 & $5 \%$ \\
\hline \multirow{3}{*}{$\begin{array}{l}\text { Age Gro } \\
21-25 \\
25+\end{array}$} & \multirow{3}{*}{$\begin{array}{l}189 \\
111\end{array}$} & \multirow{3}{*}{$\begin{array}{l}63 \% \\
37 \%\end{array}$} & Australian & 12 & $4 \%$ \\
\hline & & & Russian & 6 & $2 \%$ \\
\hline & & & Czech & 9 & $3 \%$ \\
\hline \multirow{6}{*}{$\begin{array}{l}\text { Education } \\
\text { No higher degree } \\
\text { Bachelor's degree } \\
>\text { Bachelor's degree }\end{array}$} & \multirow{6}{*}{$\begin{array}{l}48 \\
186 \\
66\end{array}$} & \multirow{6}{*}{$\begin{array}{l}16 \% \\
62 \% \\
22 \%\end{array}$} & French & 2 & $1 \%$ \\
\hline & & & German & 9 & $3 \%$ \\
\hline & & & Indian & 26 & $9 \%$ \\
\hline & & & Indonesian & 18 & $6 \%$ \\
\hline & & & Japanese & 9 & $3 \%$ \\
\hline & & & Total & 300 & $100 \%$ \\
\hline
\end{tabular}


Table 5. Passenger Satisfaction in Accessing MICE Venues with BTS (Validated N=300)

\begin{tabular}{|c|c|c|}
\hline Factor & $\begin{array}{l}\text { Agreed and } \\
\text { strongly } \\
\text { agreed } \%\end{array}$ & $\begin{array}{l}\text { Indicated } \\
\text { otherwise } \%\end{array}$ \\
\hline $\begin{array}{l}\text { 1. The BTS stations and transits are accessible to MICE venues without } \\
\text { any problem }\end{array}$ & $70 \%$ & $30 \%$ \\
\hline 2. Punctuality of BTS trains to MICE venues is precise and unfailing & $69 \%$ & $31 \%$ \\
\hline $\begin{array}{l}\text { 3. Frequency of BTS trains is sufficient with regard to the number of pas- } \\
\text { sengers in MICE venues }\end{array}$ & $38 \%$ & $62 \%$ \\
\hline 4. BTS service continuity is time and space manageable & $68 \%$ & $32 \%$ \\
\hline $\begin{array}{l}\text { 5. BTS trains speed is satisfactory with regard to the traffic situation in } \\
\text { MICE venue areas }\end{array}$ & $72 \%$ & $28 \%$ \\
\hline 6. Traveling to MICE venues by BTS is comfortable regardless of seasons & $52 \%$ & $48 \%$ \\
\hline $\begin{array}{l}\text { 7. Information about MICE venues and/or event schedules is sufficient in } \\
\text { the BTS stations or trains }\end{array}$ & $18 \%$ & $82 \%$ \\
\hline 8. Timetables on the BTS stations and transits reflect the MICE events & $22 \%$ & $78 \%$ \\
\hline $\begin{array}{l}\text { 9. Overall passenger satisfaction with BTS to access MICE venues in } \\
\text { Bangkok }\end{array}$ & $66 \%$ & $34 \%$ \\
\hline 10. BTS fare to MICE venues is affordable & $55 \%$ & $45 \%$ \\
\hline
\end{tabular}
Source: Author. Adapted and modified from Pavlina (2015)

The rationale behind this partnership scheme between the Bangkok Mass Transit System (BTS) and MICE corporations are based by several studies in integrated public transport system with tourism destinations. The study also has attempted to explore and recommend the current phenomenon where responsive governance and initiative on public transport and travel providers in Bangkok are still insignificant. Looking back to the United Kingdom, the research on tourists and/or passenger satisfactions toward the availability and suitability of public transportation systems have been long embedded within a framework of public policy (Page, 1994). Despite the evolving process, the development of the UK's public transport has always deemed the necessity of decision making on "service encounter and travel experience" (Page, 1999, p. 129). Page (1999) highlighted the policy framework from which the planning measures must indicate the implementations of tourist congestion in large urban areas. At this stage. Government support lies firmly on an extended management of tourist traffic in the outer cities, collaborati- on and/or integrative promotion (both public and destination management) during the low-season, navigation of the actual forecast of traffic and direct promotion to the tourists, well-established and networked public transports, and the implementation of the integrations both within the public transport providers, and public-private partnerships (Page, 1999), which in this case, the MICE corporations. Of general travel and tourism support, Hall (1999, p 181) explained the variety of roles in tourist transport: (1) Linking the origin market with the tourist destination; (2) Providing access and mobility within a wide destination area (region or country); (3) Offering access and mobility within a tourist attraction; (4) Providing travel along a recreational route.

The vitality of progressing the collaborative initiative between the mass transport systems and the travel and tourism industry also premised based on previous transport-tourism economic research. Albalate and Bell (2009) emphasized the role of public transport within a global flow of tourists - whereby the collaboration with the city administrators, including busines- 
Table 6. In-depth interview - Partnership simulation of Bangkok Mass Transit System (BTS) and MICE corporations as adapted from England's Strategic Action Plan for Tourism 2010-2020

\begin{tabular}{lll}
\hline ACTION & LEAD PARTNER (S) SCHEME & PROPOSED DELIVERY PARTNERS \\
\hline $\begin{array}{l}\text { i. Identify ways to minimize weekend and Thailand public } \\
\text { holidays rail closures and other such events through investi- } \\
\text { gating alternative maintenance solutions and/or scheduling }\end{array}$ & Bangkok Mass Transit System (BTS) & $\begin{array}{l}\text { Ministry of Transport (MoT); Thailand Department of Land Trans- } \\
\text { port; Local Authorities/Bangkok Metropolitan Region (BMR); } \\
\text { Thailand Convention and Exhibition Bureau; MICE venues; desti- }\end{array}$ \\
$\begin{array}{l}\text { nation organizations, Tourism Authority of Thailand (TAT) } \\
\text { (T) }\end{array}$ & &
\end{tabular}

"Currently, we do not have any agreement/cooperation with MICE corporations to address the possibilities of alternative maintenance solutions during the weekends or Thailand public holiday. The agreement of continuous services of BTS is, however, being oversight closely by local authorities and it is strictly a one-way process between BTS and Bangkok's authorities (e.g. MoT, BMR). Meanwhile, TAT would only come after with its support (e.g. tourism promotion, possibly MICE, etc.) once city administration confirmed." BTS

\begin{tabular}{lll} 
ACTION & LEAD PARTNER (S) SCHEME & PROPOSED DELIVERY PARTNERS \\
\hline $\begin{array}{l}\text { ii. Identify examples of best practice in the coordination of } \\
\text { public transport services between BTS and MICE corpora- }\end{array}$ & BTS and MICE Corporations & $\begin{array}{l}\text { BMR, Destination Organizations; transport operators; Thailand } \\
\text { Convention and Exhibition Bureau; MICE venues }\end{array}$
\end{tabular}
public
tions.

"We have not initiated any kind business agreement in the current time on BTS leisure services to MICE venues, leisure traffic management specified only to MICE destinations and the works are normally done by either Thailand Convention and Exhibition Bureau or Bangkok's city tourism." BTS

"Meanwhile, integrated transport infrastructures, for example, directions and transits from the airport to major international venues, are clearly established by Bangkok's authorities despite no exclusive business agreement between us (BTS \& MICE corporations)." BTS

"Due to the inexistence of business agreement, the information sharing options to all travelers on public transport prior to the events, have always been initiated by MICE corporations alone. BTS provides advertising channels for this purpose. And so far, we have worked with Thailand Convention and Exhibition Bureau or Thailand Authority of Thailand on an event basis, allowing access to event ticket deals. Meanwhile with BTS, so far only for "on-board" marketing deals" MICE corporation 1-6

ACTION LEAD PARTNER (S) SCHEME PROPOSED DELIVERY PARTNERS

iii. BTS and MICE corporations work with operators to BTS and MICE Corporations Thailand Convention and Exhibition Bureau; MICE venues; Tour$\begin{array}{ll}\text { achieve greater coordination in terms of information provi- } & \text { ism Authority of Thailand (TAT); Destination Organizations; Ac- }\end{array}$ sion, communication and timetabling. commodation and airport services

"In terms of information support, BTS marketing team are very welcoming to support the channels for advertisements, either inside the train or inside BTS's station/ transit areas." MICE corporation I

"With prior communications/agreement, BTS would have actual records of events/activities which will be held around BTS areas. If that event is big enough, we will consider the offer of promotion on a case by case basis. Then BTS will provide a 1-day ticket deal to MICE organizers and the condition of this ticket has to be used within 1 year after the date of purchase. This also includes the recommendation of selective hotels/accommodation partners or transport to the airports. However, an official, binding long-term, specific BTS-MICE corporations' agreement is yet to be available." BTS.

"So the business agreement between BTS and MICE businesses is not tightened by clear partnership agreement, not is it advised by either Tourism Authority of Thailand, destination offices, or Thailand Convention and Exhibition Bureau. " MICE corporation 2 \& 3.

"For example, during the preparation of the events, the organizers will intentionally approach BTS for the purpose of promotional tickets and advertisement (whenever necessary)." MICE corporation 4 \& 5 .

"As we always try our best to hold the events near BTS stations, for a better crowd purpose, we thought that we are better off with a fixed business agreement with BTS so the work can be done more efficiently. And local authority can help this happens by enabling industry discussions/networking - especially Thailand Convention and Exhibition Bureau." MICE corporation 1-6.

ACTION $\quad$ LEAD PARTNER (S) SCHEME PROPOSED DELIVERY PARTNERS

iv. Promote use of travel plans for MICE travel purpose, BTS Thailand Convention and Exhibition Bureau; MICE venues BTS delivering tourism services.

"As much as we focus on tourists' travel experiences, our main target is broad to all tourists, not specific only for MICE travelers. Thus, the action plan on supporting MICE business from the external MICE tourist demands, other than promotional ticket and advertisement, has not yet existed. Later in the future, we may have the opportunity to collaborate with your proposed partners, MICE corporations or TCEB." BTS

ACTION LEAD PARTNER (S) SCHEME PROPOSED DELIVERY PARTNERS

v. Simplify and improve rail pricing, ticketing restrictions BTS and packages for leisure users e.g. development of smart cards for leisure users.

"Integrated tourist tickets and MICE events tickets are available on the basis of agreement - normally organizers will reach out to us." BTS

ACTION LEAD PARTNER (S) SCHEME PROPOSED DELIVERY PARTNERS

vi. Work with MICE Corporations to influence leisure jour- BTS and MICE Corporations ney times and minimize peak period and holiday disruption.

"As we are hands off of this policy process, we would hope Thailand Convention and Exhibition Bureau or Bangkok's local authority could advocate on this corporation with BTS. For example, prioritizing or providing special passenger lines of MICE events during peak periods and/or clear event boards in their stations/transits." MICE corporation 3

ACTION LEAD PARTNER (S) SCHEME PROPOSED DELIVERY PARTNERS

vii. Encourage coordination between the transport sector BTS and MICE Corporations and major events through identifying and sharing case studies on the benefits of working together. Demonstrate that transport, tourism and wise growth can work together and offer solutions to transport problems for visitors, employes and residents alike.

"Calling for a public meeting between BTS, MICE corporations and other public transportation modes in the greater Bangkok area for addressing/promoting and setting chapters of this integrated cooperation." MICE corporation $5 \& 6$

"In addition to the BTS passenger satisfaction study, with a good satisfaction rate from the study, a special partnership scenario should be created between BTS and MICE Corporations as the MICE business in Bangkok is growing exponentially. The efforts could also promote the overall tourist infrastructure of Thailand leading to continuous good tourist experience." MICE corporation 2 ism Authority of Thailand (TAT); Destination Organizations; Accommodation and airport services 
ses are imperative. And as Sarma (2003) resonated in his study within Northeast India's destination, that the tourists' decision-making process also considers heavily on the availability of integrated, and sufficient public transports. Thus, unfulfilled integrations would hinder the travel decisions to a destination, leaving a city/region with less economic competitiveness (Khadaroo \& Seetenah, 2008).

\section{CONCLUSION}

This research has a clear yet arguable conclusion on the lack of strategic policy guidance on partnership between the mass public transport and private travel and tourism enterprises like MICE corporations. The findings have strongly indicated that the independence and business confidence of BTS as a huge transport enterprise is mostly influenced by a stagnant government policy support. It has been hindering the outreaches of MICE corporations to BTS's initiatives, leaving these two, what was supposed to be an interchangeable partner in Thailand's travel and tourism sectors, less acquainted.

When putting the BTS and MICE corporation's partnership scheme in the context of England's Strategic Action Plan for Tourism 2010-2020, the novelty of this study underpins critical arguments (both reflected from satisfaction surveys \& interviews): (1) the frequency of BTS trains and regulated transits system should be addressed to avoid unsecured and packed readership environment, (2) when official, long-term, and regulated partnership is endorsed by Bangkok authorities, MoT, TAT, and TCEB, the availability of information about MICE venues and/or event schedules, the actual timetables on the BTS stations and transits that reflect the MICE events, as well as more affordable BTS's tickets to MICE events would cater to the needs of BTS riders during their trips to
MICE venues, enabling more ridership's service satisfaction and trust. After all, as the Thailand government has clearly divided the authorized bodies for respective MICE, transport, and public-private destination management, an enforced integration between BTS and MICE corporations should likewise be deemed critically. That would eventually help encourage the creation of a smart travel systems for Bangkok and Thailand as a whole.

\section{REFERENCES}

Abeyratne, R. (1993). Air transport tax and its consequences on tourism. Annals of Tourism Research, 20(3), 450-460.

Albalate, D., \& Bel, G. (2009). Tourism and urban public transport: Holding demand pressure under supply chain constraints. Tourism Management, 31(2010), 425-433.

Antonucci, L., Crocetta, C., FD d'Ovidio., \& Toma, E. (2014). Passenger satisfaction: A multi-group analysis. Quality and Quantity, 48(1), 337-345.

Bangkok Mass Transit System (2019). Company profile and business. Retrieved from https:/www.bts.co.th/ eng/info/info-history.html on December 10, 2019.

Bank of Thailand (2021). White paper: Revitalising Thailand's tourism sector. Retrieved from https://www.bot.or.th/ Thai/MonetaryPolicy/EconomicConditions/AAA/250624 WhitepaperVISA.pdf on September 15, 2021.

Celiński, I., \& Sierpiński, G. (2014). Real time model for public transport management. Scientific Journal of Logistics, 10(1), 31-41.

Chew. J. (1987). Transport and tourism in the year of 2000. Tourism Management, 8(2), 83-85.

e-ISSN 2407-392X. p-ISSN 2541-0857 
de Ona, J., de Ona, R., \& Calvo, F. J. (2012). A classification tree approach to identify key factors of transit service quality. Expert Systems with Applications, 39(12), 11164-11171.

England Strategic Action Plan (20102020). Retrieved from https://www. nationalparksengland.org.uk/ data/ assets/pdf_file/0029/26597/Visit-England-Transport-and-Tourism-ActionPlan-ENPAA-response-March-2012. pdf on August 1, 2020

Goulding, C. (2017). Navigating the complexities of grounded research in advertising. Journal of Advertising, 46(1), 61-70.

Gronau, W., \& Kagermeier, A. (2007). Key factors for successful leisure and tourism public transport provision. Journal of Transport Geography, doi: 10.1016/j.jtrangeo.2006.12.008

Hall, D. R. (1999). Conceptualising tourism transport: Inequality and externality issues. Journal of Transport Geography, 7(3), 181-188.

Kaul, R. (1985). Dynamics of tourism: A trilogy, 111. New Delhi: Transportation and Marketing.

Khadaroo, J., \& Seetenah, B. (2007). Transport infrastructure and tourism development. Annals of Tourism Research, 34(4), 1021-1032.

Krungsri (2019). Mass rapid transit operators: Thailand industry outlook 2019-21. Retrieved from https://www.krungsri.com/bank/ getmedia/71e66d1b-5790-44f282dc-4c1e8509f193/IO_Mass_Transit 190513 EN EX.aspx on January 12,2020 .

Lumdson, L., \& Page, S. J. (2004). Tourism and transport: Issues and agenda for the new millenium. Oxford: Elsivier.
McIntosh, R. W., Goeldner, C. R., and Ritchie, J. R. B. (1995). Tourism: Principles, practices, philosophies. New York: John Wiley and Sons.

Meet in Thailand (2020). Retrieved from https://www.meetinthailand.com/business-event on July 20, 2020.

Mill, R. C., \& Morrison, A. M. (1992). The tourism system: An introductory text. Englewood Cliff New Jersey: Prentice Hall.

Ministry of Tourism and Sport (2021). International Tourist Arrival. Retrieved from https://www.mots.go.th/mots en/more_news_new.php?cid $=330$ on September 15, 2021.

Mouwen, A. (2015). Drivers of customer satisfaction with public transport services. Transportation research: Part A: Policy and Practice [serial online], 78, 1-20.

Noichan, R., \& Dewancker, B. (2018). Analysis of accessibility in urban masss transit node: A case study in Bangkok transit station. Sustainability, 10(4891); doi:10.3390/su10124819.

OECD. (2017). OECD economic surveys United Kingdom. Retrieved from http://www.oecd.org/economy/surveys/United-Kingdom-2017-OECDeconomic-survey-overview.pdf on August 5, 2019.

Ortujzar, J. D., \& Willumsen, L. G. (1991). Flexible long range planning using low cost information. Netherlands: Kluwer Academic Publishers.

Page, S.J. (1994). Transport and tourism global perspectives (2nd edn.). Harlow: Pearson/Prentice Hall.

Page, S. J. (2005). Tourism and transport: Global perspective (2nd edn.). Harlow: Pearson/Prentice Hall. 
Pavlina, P. (2015). The factors influencing satisfaction with public city transport: A structural equation modelling approach. Journal of Competitiveness, 7(4), 18-32.

Prideaux, B. (2000). The role of the transport system in destination development. Tourism Management, 21(1), 53-63.

Replogle, M. A.., \& Fulton, L. (2014). A global high shift scenario: Impact and potential for more public transport, walking, and cycling with lower car use. New York: Institute for Transportation and Development Policy (ITDP). Retrieved from: http://www.itdp.org/ wp-content/uploads/2014/09/A-Global-High-Shift-Scenario_WEB1.pdf on August 5, 2019.
Sarma, M. K. (2003). Towards positioning a tourist destination: A study of Northeast India. ASEAN Journal on Hospitality and Tourism, 2(2), 104-119.

Shaw, E. (1999). A guide to the qualitative research process: Evidence from a small firm study. Qualitative Marketing Research: An International Journal, 2(2), 59-70

Shiau, W., \& Luo, M. M. (2012). Factors affecting online group buying intention and satisfaction: A social exchange theory perspective. Computer in $\mathrm{Hu}$ man Behaviour, 28(6), 2431-2444.

TCEB (2019). MICE: Promising key industry. Retrieved from https://www. businesseventsthailand.com/en/keyindustries on December 10, 2019. 